\title{
Public Participation by Optimizing Rural Spatial Planning to Prevent Functional Conversion of Agricultural Land to Non-agricultural Use
}

\author{
Rofi Wahanisa*, Aprila Niravita, Muh. Afif Mahfud, Siti Aminah \\ Department of Agrarian Law, Faculty of Law, Semarang State University, Indonesia
}

Received June 21, 2021; Revised August 9, 2021; Accepted September 8, 2021

\section{Cite This Paper in the following Citation Styles}

(a): [1] Rofi Wahanisa, Aprila Niravita, Muh. Afif Mahfud, Siti Aminah, "Public Participation by Optimizing Rural Spatial Planning to Prevent Functional Conversion of Agricultural Land to Non-agricultural Use, "Universal Journal of Agricultural Research, Vol. 9, No. 5, pp. 149 - 155, 2021. DOI: 10.13189/ujar.2021.090501.

(b): Rofi Wahanisa, Aprila Niravita, Muh. Afif Mahfud, Siti Aminah (2021). Public Participation by Optimizing Rural Spatial Planning to Prevent Functional Conversion of Agricultural Land to Non-agricultural Use. Universal Journal of Agricultural Research, 9(5), 149 - 155. DOI: 10.13189/ujar.2021.090501.

Copyright $\bigcirc 2021$ by authors, all rights reserved. Authors agree that this article remains permanently open access under the terms of the Creative Commons Attribution License 4.0 International License

\begin{abstract}
Spatial planning in a region is necessary to be carried out. Spatial planning is a realization of planning a region how it will be developed or maintained. It becomes the basic principle within all sequences of spatial planning in a region. Regional spatial planning can involve urban and rural areas. Good spatial planning can make significant contribution to prevent functional conversion from agricultural land into non-agricultural land which is getting massive. Therefore, this study discusses and analyses the functional conversion from agricultural land into non-agricultural land as well as the strategy of public participation in spatial planning to prevent the conversion, particularly in Munding village in Bergas sub-district in Semarang regency. This study used a qualitative method which revealed truth based on the results of factual data collection during the research. The research is conducted according to observation of natural background or social environment producing descriptive data. The result shows that strategy that can be used to prevent agricultural land conversion is socialization, which educates the people and public participation. Public participation is important to increase the knowledge of people about every stage of spatial planning and license to limit conversion of agricultural land.
\end{abstract}

Keywords Spatial Planning, Functional Conversion, Agricultural Land, Public Participation

\section{Introduction}

The Constitution of the Republic of Indonesia stated that Indonesia is a state of law. Consequently, things related to general prosperity are regulated by laws in the form of written regulations. State, as a power organization, is not only responsible for the implementation of governmental power, laws, and public order but also the realization of general prosperity. Koesoemaatmadja [1] argues that the main objective of the implementation of laws, if reduced to only one point, is to create order. It is the pivotal and foremost goal of all laws, and the need for this goal becomes the fundamental requirement for creating a well-ordered society. The implementation of laws, besides, is intended to achieve justice which embraces distinct contents and measures, depending on the existing society.

Land is a place where humans carry out living activities in the past, present and future. In every attempt to use land, forest, and mine, there are regulations. They are intended for the interests of the owner(s) and the state who aim to protect general interests [7]. Salindeho [8] argues that land is a thing having economic value according to the Indonesian people's view. It often prompts disputes at peace, causes conflicts in a society, and creates problems in realizing development. Land is also defined as a physical environment which consists of climate, relief, soil, water, and vegetation as well as the objects above as 
long as they are related to land use, including the results of human activities in the past and present, such as marine reclamation, vegetation clearance, and harmful results [9]. In the agrarian law, land does not deal with every aspect, but it is considered from its juridical aspect which is directly related to land rights. Land is a part of the earth's surface as stipulated in Article 4 section (1) of the Basic Agrarian Law (BAL) that in land acquisition rights, mentioned in Article 2, there are different types of rights on the earth's surface (referring to land) which can be owned by individuals, collectives, or legal entities. Furthermore, Article 9 section (2) states that every Indonesian citizen, both man and woman, has equal opportunity to obtain land rights and benefits both from themselves and their families [2]. There are several publications which discuss about agricultural land conversion including Ramsey \& Corty [3] which analyze the cause of land conversion and make prediction about the width of agricultural land that will be lost. It is different from this article in several aspects, for example, it uses an economical perspective while this article uses legal perspective. Agricultural land conversion was also discussed by Li Jiang et al., [4] article but his article on impact of industrialization toward agricultural land use intensity. This article does not consider public participation in solving this problem which is the key solution we offer in this article.

The conversion of land function always occurs in undertaking social-economic activities along with the growth of rural population. Due to constant amount as well as growing demand, land function is likely to be converted into the one used for more profitable activities based on the surrounding potential. However, the national policy on controlling functional conversion of agricultural land often contradicts that of the regional government who prioritize local and regional interests. The implementation of policy on controlling functional conversion is still considered relatively effective in limiting the use of agricultural land for non-agricultural purposes through the mechanism of location license and spatial planning. In fact, there are still many speculator' behaviors which are not reached by the implementation of this policy. This study discusses and analyses the functional conversion from agricultural land into non-agricultural land as well as the strategy of public participation in spatial planning to prevent the conversion, particularly in Munding village in Bergas sub-district in Semarang regency.

\section{Methods}

This study used a qualitative method, which revealed truth based on the results of factual data collection during the research in Munding village in Bergas sub-district in Semarang regency. A qualitative method is a research procedure that produces descriptive data from literature, expressions, and behaviors [5]. The interviews were conducted with relevant stakeholders like the village head to analyze the urgencies of public participation in maintaining spatial planning in Munding village regarding the prevalence of functional conversion from agricultural land to non-agricultural land.

With regard to this description, it is reasonable to argue that qualitative research is a research procedure emphasizing the research based on theories, concepts, definitions, and characteristics. The research is conducted according to one's observation of natural background or social environment producing descriptive data. Descriptive data refers to verbal and pictorial data [6]. The analysis was conducted with descriptive supported by descriptive statistics to reveal the land use specifically in Munding village in Bergas sub-district and Semarang regency.

\section{Result}

\subsection{Research Location}

Munding village has a total area of 178.495 hectares, $41.58 \%$ ( 74.225 hectares) of which is used for crop fields and $58.42 \%$ (104.270 hectares) non-agricultural fields. These non-agricultural fields consist of yards and buildings (27.030 hectares), forests (75.240 hectares), and other dry land ( 2 hectares). It is obvious that within the last 5 years the agricultural land has been rapidly converted into non-agricultural land such as housing/building, forest, swamp, river, and cemetery. The use of field area within 2012-2017 declined by 25.45 hectares, and that of non-field area suffered decline by 8.22 hectares as well. The functional conversion which is increasingly prevalent in Bergas sub-district has negative impacts on its villages, including Munding village (Table 1).

Table 1. Geographic Conditions of Land Use of Research Object

\begin{tabular}{|c|c|c|c|}
\hline Land Use & Total & Unit & percentage \\
\hline Total area: & 178.495 & hectares & $100 \%$ \\
\hline crop fields & 74.225 & hectares & $41.58 \%$ \\
\hline $\begin{array}{c}\text { non-agricultural fields } \\
\text { Total of non-agricultural } \\
\text { fields }\end{array}$ & 104.270 & hectares & $58.42 \%$ \\
\hline buildings & 27.030 & hectares & $25.92 \%$ \\
\hline dryland & 75.240 & hectares & $72.16 \%$ \\
\hline other & 2 & hectares & $1.92 \%$ \\
\hline
\end{tabular}

\subsection{Functional Conversion from Agricultural into Non-agricultural Land}

Agricultural land is commonly used for agricultural business including crops, forest, fisheries, plantation, dryland, fields, grazing, and other types of use normally regarded as agricultural business. This definition can be a benchmark for categorizing land into agricultural and 
non-agricultural land, and each of them has different functions [10]. According to Harsono [10], non-agricultural land refers to land used for non-agricultural business or activities. The use of non-agricultural land involves some purposes. The first is land use for industries. Land used for industries is significantly needed due to the increasing number of factories. In addition to producing goods and services needed by the society, developing industries also provides employment, gives business opportunities, generates public income, encourages regional development, and utilizes the existing natural and human resources. The land used for industries is commonly intended for buildings, warehouses, tied cottages, administration offices, etc. The second is land used for housing. The amount of land used for housing is significantly needed because of the population growth. Housing is built in several locations both in urban and rural areas. The third is land used for companies. The amount of land used for companies is increasingly needed, as well, for developing businesses such as markets, department stores, warehouses, banks, theaters, hotels, train stations, etc. The fourth is land used for services. Service sector also requires a large amount of land. The land is intended for a number of services including transportation services (land transportation) such as roads, bus stations, bus-shelters, railways, etc.; trade services such as department stores, shops, markets, warehouses, etc.; educational services such as schools, universities, training centers, libraries, and sport arenas; religious services such as mosques, churches, chapels, temples, and pagodas. Health services such as health centers, clinics, hospitals, and pharmacies. Recreational services such as art buildings, theaters, parks, and zoos; governmental and private services such as government and private buildings; security services such as local security stations, police stations, military bases, weapon storages for army and police. The fifth is functional vacant land. This land is basically intended for a particular purpose.

After describing land, agricultural and non-agricultural land, the following discussion deals with the definition of functional conversion of agricultural land. Based on Government Regulation No.1/2011 on establishment and functional conversion of sustainable crop areas, it is stated that the conversion refers to functional shift from sustainable crop areas to non-sustainable crop areas either temporarily or permanently. Functional conversion of land can be regarded as the act of converting land use from an activity to another. The conversion arises because of development and population growth. Population growth and increasing demand for development activities have changed the ownership structure and land use continuously [11]. In addition, conversion of agricultural land basically occurs as a result of competition between agricultural and non-agricultural purposes. The competition is caused by three social economic phenomena: 1) limited land resources; 2) population growth; and 3) economic growth. Irawan [12] contend that at the micro level the process of functional conversion of agricultural land can be carried out by either farmers or other parties. The conversion undertaken by other parties has more significant impact on reducing food production capacity because it requires large amounts of land used for housing [13].

The proportion of agricultural land in Semarang regency has been stipulated in the regional government regulation of Semarang regency No. 6/2011 on 2011-2031 spatial planning as explained in Table 2. Agricultural areas consist of crop areas, horticultural areas, plantation areas, and farming areas. The crop areas is 24,340 hectares in total areas spreading in all sub-districts of Semarang regency. The crop areas used for sustainable crop is 22,896 hectares in total areas spreading in all-sub districts of Semarang regency, except Getasan sub-district. Horticultural areas is 9,046 hectares in total areas spreading in all sub-districts of Semarang regency. Plantation areas is 12,140 hectares in total which spreads in all sub-districts of Semarang regency. Farming areas consists of big-scale and small-scale farming. Big-scale farming can be located in all sub-districts outside the urban and tourism areas based on the applied regulations.

Table 2. Proportion of agricultural land in Semarang regency

\begin{tabular}{|c|c|c|c|}
\hline Agricultural areas & Total & Unit & Percentage \\
\hline crop areas & 24,340 & hectares & $35.57 \%$ \\
\hline horticultural areas & 22,896 & hectares & $33.46 \%$ \\
\hline plantation areas & 9,046 & hectares & $13.23 \%$ \\
\hline farming areas & 12,140 & hectares & $17.74 \%$ \\
\hline Total & 68,422 & hectares & $100 \%$ \\
\hline
\end{tabular}

Small-scale farming is managed in the form of farming centers in rural areas located in all sub-districts and integrated with the other agricultural activities. Frequent functional conversion from agricultural to non-agricultural land is caused by two factors. First, there are necessities to meet the needs of a growing population. Second, the demands for better life quality increase. Besides, "in practice the governance of land use can vary greatly, even within countries, let alone among them. Much depending on how local governments cooperate or compete with one another on land use issues, cities and communities face the types of pressures due to such factors as population growth or decline. The types of actors involved in land use governance and even the levels of social trust in a society, which affects relationships between and among residents, businesses, governments, and non-governmental groups. In some places, there is a wide range of informal partnerships between many actors involved in the governance of land use, while in others, there is a distinct hierarchy between levels of planning, and the institutions involved operate on the basis of statutorily defined roles [14]." This notion implies that practically land 
management varies. Even within a country, the society rely on the way the regional government work on the issue of land use. There are several factors that intensify the pressure such as population growth or decline, types of actors involved in land use, and social trust level in the society. There are several things that influence the relationship between inhabitants, businesses, government, and non-governmental parties in some places such as informal partnership between the actors involved in land management and different hierarchy between the planning level and the institutions involved as stipulated in laws.

Based on the notions above, there are some factors for functional conversion of agricultural land to non-agricultural land as follows.

\section{a External factors}

External factors refer to the factors caused by the dynamics of urban development, demographics, or economy. Demographics in this case refer to the population growth which leads to increasing demands for land used for housing. The rapid growth of population is considered one of the causes of decline in rice production. Economic factors refer to the increasing needs of land in the economic sector such as tourism or trading activities. Besides, economic pressure during a crisis can also prompt the functional conversion. This condition forces farmers to sell their fields to meet their life necessities. Thus, it increases the conversion rate as well as the land acquisition by capital owners. Urban development refers to the high density of urban areas leading to expansion into rural areas. The rural areas that provide food supplies for urban areas become denser due to the rapid growth of urban areas. Consequently, the productive agricultural areas will be converted into housing or industries.

\section{b Internal factors}

Internal factors tend to look at the functional conversion caused by social economic conditions of the agricultural household of the owners. It cannot be denied that because of the development of the modern era, the younger generations tend to work in the industrial sector or office rather than in the agricultural sector. This situation leads to lack of productive workers in the agricultural sector in rural areas as most of them move to urban areas. Moreover, rising operational costs in managing agricultural land also makes the farmers suffer losses so that they choose different professions and sell their fields.

\section{c Policy factors}

Policy factors are related to the aspects of regulations issued by the central and regional government regarding functional conversion of agricultural land. The weaknesses of these regulation aspects lie in the legal force, violation sanction, and accuracy of land objects prohibited from being converted. Besides, lack of real action and unclear procedures from the government in minimizing the functional conversion increase the amount of the converted land.

In addition to those three factors, there are other things that influence functional conversion of agricultural land. First, along with the development of housing or industrial areas in a converted land, the accessibility in that location becomes more conducive for housing and industries that eventually increases demands for land from investors or speculators so that the price of surrounding land rises. Second, the rising price can trigger the farmers to sell their land [12]. However, despite those factors, functional conversion from agricultural land into non-agricultural land certainly follows the regulations in the positive laws.

The regulations of functional conversion from agricultural land into non-agricultural land are stipulated in Law No. 41/2009 on protection of sustainable crop fields and Government Regulation No. 1/2011 on establishment of functional conversion of sustainable crop fields. These regulations stipulate that functional conversion can be carried out by fulfilling several requirements. 1) The first requirement is strategic proper study. Viewed from the perspective of general interest, functional conversion of sustainable crop fields can classify its functions into big-scale development, mid-scale development, and small-scale development orienting towards national and regional levels where mid-scale development is provincial/regency-based, while small-scale development is sub-district/village-based. 2) The second requirement is ownership of the land. The one(s) responsible for the conversion acquire ownership based on the provisions in laws. Land acquisition is carried out by giving compensation to the owners. 3) The third requirement is a plan of functional conversion. The plan of functional conversion at least includes area and location which will be converted, conversion schedule, area and location of the substitution, schedule for providing the substitution land, and the use of the substitution land (Article 41 of the Government Regulation No.1/2011). 4) The fourth requirement is the availability of substitution land over sustainable crop fields.

\subsection{Strategies to Preventing Functional Conversion of Agricultural into Non-agricultural Land through Public Participation in Rural Spatial Planning}

Based on the map of 2011-2031 spatial planning of Bergas sub-district, Munding village is designated as landslide-prone area, limited production forest area, horticultural area, crop area, production forest area, and water infiltration area. Thus, Munding village plays a significant role in providing space and facilities in order to strengthen the economy by developing its agricultural and tourism sectors which are sustainable and environment-oriented as regulated in the policy and strategies of developing spatial structures in Semarang regency (Figure 1). 


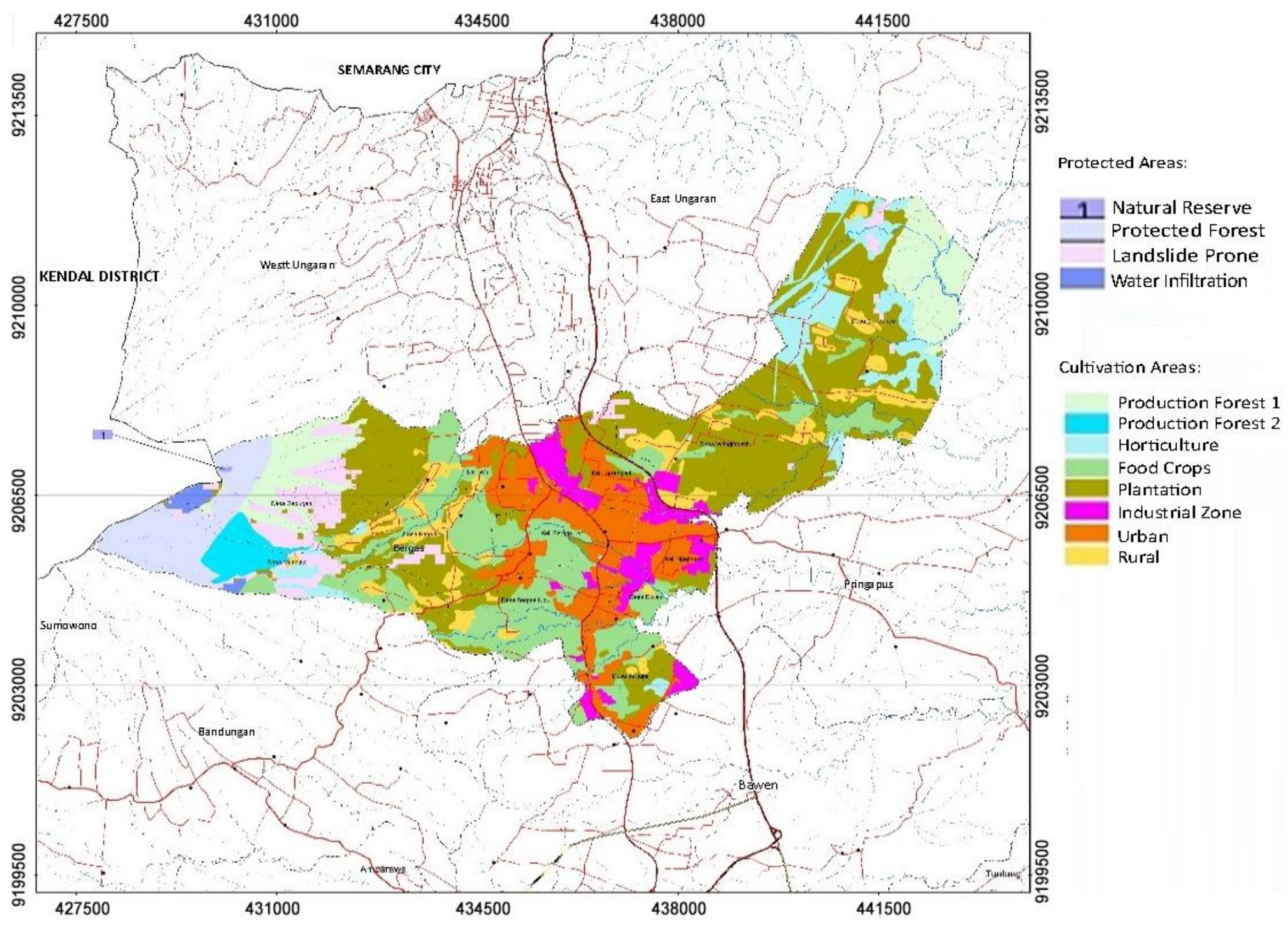

Source: Public Works Office of Semarang Regency

Figure 1. Map of Households and Hamlets in Bergas Sub-District 
The functional conversion of agricultural-land that has existed for several years is responded by the village head by involving the society to prevent further functional conversion. This action is the realization of public involvement. Public participation becomes a strategy in preventing functional conversion from agricultural land into non-agricultural land that is getting massive. Etymologically, the word participation means taking part in which a participant takes part or is involved. Therefore, participation can refer to the action of taking part or being involved in a particular activity. There is one's mental and emotional involvement in a group which encourages the group to achieve a particular objective and be responsible for the actions taken to achieve the objective [15]. Public participation becomes necessary and important in the implementation of development, including spatial planning, due to positive impacts as follows. Participation helps to achieve more results and public service can be provided with low costs through participation. Moreover, participation has an essential value for the participants because it has something to do with their pride. Participation becomes a catalyst for further development, encourages the participants to have responsibility, ensures the need of the society for being involved, ensures that the work is carried out in the right direction, becomes a means of obtaining and applying knowledge from the society in order to combine different skills, and reduces dependence upon one's skills. In addition, participation raises public awareness of the causes of poverty in order to eliminate them [16]. However, it needs to be underlined that public participation will not be realized unless approaches in the forms of socialization and advocacy are taken.

The results of an interview with Romdoniyatun, the head of Munding village show that public participation is urgently needed in maintaining spatial planning in Munding village regarding the prevalence of functional conversion from agricultural land to non-agricultural land. One of the ways to consider the conversion is observing the land condition which will be converted, whether it is eligible for the conversion, or it must be preserved. However, it cannot be denied that Munding village is located next to Bandungan, which is a tourism area and has a lot of lodges and hotels. This condition potentially makes Munding village a tourism village where development has been initiated. The prevention strategies are sometimes ineffective due to the mindset of the public that they have full authority to manage their land without considering the long-term impact. Despite this problem, the village head continuously approaches and educates the society through socialization. It corresponds to what is stated by Sadyohutomo [17] that public participation will not be realized unless approaches in the forms of socialization and advocacy are taken.

In addition to public involvement in preventing functional conversion from agricultural to non-agricultural land, policies from the central or regional government need to be strengthened as well. Controlling functional conversion from agricultural land into non-agricultural land is important as it is closely related to the realization of spatial planning which aims to create national space which is safe, comfortable, productive, sustainable, and based on archipelagic vision and national resilience. This goal can be seen from some indicators: a) achieving harmony between natural and artificial environment; $b$ ) achieving integration in using natural and artificial resources by considering human resources; and c) realizing protection on spatial function and prevention of the negative impacts from spatial use [2].

One of the instruments which can be used to regulate functional conversion is licensing mechanism. In this case, license refers to an instrument in administrative law. The government issue a license as a juridical means to control public behaviors. License functions as an approval from the authority based on laws or government regulation for a particular situation which does not conform to the provisions in laws. License allows the applicants to carry out a prohibited action for general purposes that require special supervision [18]. Besides, Bagir Manan, as quoted by Sutedi [19], argues that license can be defined as an approval from the authority based on legislation in order to give permission to carry out a particular activity which is generally prohibited.

This licensing mechanism corresponds to the implementation of critical law theory stated by Robert M. Unger who explains that rule of law is defined through an idea about neutral, similar, and predictable characteristics. This definition emphasizes that in the conception of rule of law, using government authority in a state must be carried out within the boundaries of the applied regulations. Every regulation must be equally applied for all society in order to make sure that spatial planning, spatial use, and spatial control are achieved as expected. As the realization of public participation in preventing functional conversion from agricultural land into non-agricultural land, the licensing mechanism can be applied in Munding village in which the society apply for license to the government of Semarang regency, officially stating whether the land is eligible for building or not. If the society are willing to carry out a particular action to the owned land such as putting up buildings, they must have a license, in this case a building permit $[20,21]$. The regency and village authority also continuously give socialization in order to raise public awareness of spatial planning as regulated in Law No. 26/2007 on spatial planning and Government regulation No. 68/2010 on types and means of public involvement in spatial planning by village authority [22]. Some strategies which can be implemented are raising awareness, policy advocacy, institutional building, and capacity building [23] Therefore, public participation in spatial planning becomes relevant in order to develop a region - spatial planning which represents public interests and creates 
pleasant environments.

\section{Conclusions}

The result shows that strategy that can be used to prevent agricultural land conversion is socialization and educating the people and public participation. Public participation is important to increase the knowledge of people about every stage of spatial planning and license to limit conversion of agricultural land. Functional conversion from agricultural land into non-agricultural land is unavoidable. Therefore, the strategies which can be employed by the government (regency or village level) is applying regulation in order to prevent massive and rapid functional conversion from agricultural land into non-agricultural land as well as educating and giving socialization to the society in order to raise their awareness of preventing this conversion.

In order to realize public participation, collaboration with related parties needs to be initiated such as universities, non-governmental organizations, public figures, people's representative council, and other parties. Some strategies which can be implemented are raising awareness, policy advocacy, institutional building, and capacity building. Therefore, public participation in spatial planning becomes relevant in order to develop a region - spatial planning which represents public interests and creates pleasant environments.

As practical implications, public participation of Munding society in maintaining spatial planning of their village from functional conversion from agricultural into non-agricultural land is an activity in the realization stage of spatial planning, spatial use, and spatial use control. In addition to public participation in spatial planning, licensing instruments can also be used as a regulation to limit functional conversion from agricultural land into non-agricultural land.

\section{REFERENCES}

[1] Koesoemaatmadja M., "Functions and Development of Law in Development," Jakarta: Bina Cipta, Bandung, 2002.

[2] Andriansyah, Sulastri E., Satispi E., "The role of government policies in environmental management," Research Horizon, vol. 1, no. 3, 2021.

[3] Ramsey A. F., Corty F. L., "Conversion of Prime Agricultural Land to Nonagricultural Uses in One Area of the Sunbelt," Journal of Agricultural and Applied Economics, vol. 14, no.2, pp. 23-29, 1982.

[4] Jiang L., Deng X., Seto K. C., "The impact of urban expansion on agricultural land use intensity in China," Land use policy, vol. 35, pp. 33-39, 2013.
[5] Ashshofa B., "Legal research methods," Jakarta: Rineka Cipta, 2007.

[6] Moleong L., "Qualitative Educational Research Methods," Bandung: Alumni, 2010.

[7] Muchsin I. K., Koeswahyono I, "Aspects of Legal Policy on Land Use and Spatial Planning," Jakarta: Sinar Grafika, 2008.

[8] Salindeho J., "Land Issues Under Development," Jakarta: Sinar Grafika, 1987.

[9] Rayes M. L., "Land resource inventory method," Yogyakarta: Andi 2007.

[10] Harsono B., "Indonesian Agrarian Law, History of the Formation of Basic Agrarian Laws, Content and Implementation, Volume 1: National Land Law," Jakarta: Djambatan, 2008.

[11] Sasono A., Husein A. S., "Political Economy of Land Tenure,” Jakarta: Pustaka Sinar Harapan, 1995.

[12] Irawan B., "Rice field conversion: potential impacts, patterns of use, and determinants," Forum Penelitian Agro Ekonomi, vol. 23, no. 1, pp. 1-18, 2016.

[13] Widjanarko B. S., Pakpahan M., Rahardjono B., Suweken P., "Aspects of land in controlling the conversion of agricultural land (rice fields)," Prosiding Multi-fungsi Lahan Pertanian, Jakarta, 2001.

[14] Krawchenko T., Schumann A., "The use of land: Why planners cannot go it alone," OESC, 2017, Retrieved from https://www.oecd-ilibrary.org/docserver/67d3e084-en.pdf? expires $=1625425952 \&$ id $=$ id $\&$ accname $=$ guest $\&$ checksum $=$ C2A097B6E7115AF2CB7EE9BEA49C4370.

[15] Putranto R., “Development Project Management," Jakarta: Lembaga Penelitian FE-UI, 26, 1992.

[16] Ariyadi W., "Empirical Analysis of Farmers Household Food Security Levels in Salatiga, Indonesia," Research Horizon, vol. 1, no. 1, 2021.

[17] Wahanisa R., Hidayat A., Anggono B. D., "The nuisance ordinance in the establishment of commercial buildings and legal enforcement of spatial planning at the regional government level," Journal of Legal, Ethical and Regulatory Issues, vol. 22, no. 6, pp. 1-7, 2019.

[18] Syarief E., "Electronic land certificate: Its goals and challenges," Research Horizon, vol. 1, no. 4, 2021.

[19] Sutedi A., "Licensing law in the public service sector," Jakarta: Sinar Grafika, 2010.

[20] Yuvaraj R. M., “Assessment of Land Use/Land Cover and Its Dynamic Using Geospatial Techniques in Pudukkottai District of Tamil Nadu, India," Environment and Ecology Research, vol. 8, no. 4, pp. 85 - 99, 2020. DOI: 10.13189/eer.2020.080401.

[21] Wahanisa R., Hidayat A., Riyanto R. B., Anggono B. D., "Problems of disputes/conflicts over land acquisition towards development for public interest in Indonesia," International Journal of Criminology and Sociology, vol. 10, pp. 320-325, 2021.

[22] Soetjipto N., Kurniawan G., Sulastri Riswanto A. "The 
Influence of Employee Discipline, Learning and Supervision on the Service Performance of Public Works in Bina Marga Office of Ponorogo Regency," Research Horizon, vol. 1, no. 4, 2021.

[23] Padilla N. E., Payne J. A. G. Simbulan V. S., Lapastura R. J.
S., Cadeliña E. J. A., "Capacity Building for Dairy Farmers towards Commercialization of Green Corn Silage, Haylage and Urea Molasses Mineral Block," Universal Journal of Agricultural Research, vol. 8, no. 6, pp. 233 - 240, 2020. DOI: $10.13189 /$ ujar.2020.080604. 